This is a self-archived version of an original article. This version may differ from the original in pagination and typographic details.

Author(s): Eskelinen, Teppo; Perkiö, Johanna

Title: Micro-investment perspective and the potential of the universal basic income

Year: 2018

Version: Accepted version (Final draft)

Copyright: @ The Authors 2018. Development Policy Review @ 2018 Overseas Development

Rights: In Copyright

Rights url: http://rightsstatements.org/page//nC/1.0/?language=en

Please cite the original version:

Eskelinen, T., \& Perkiö, J. (2018). Micro-investment perspective and the potential of the universal basic income. Development Policy Review, 36(S2), 0696-0709.

https://doi.org/10.1111/dpr.12304 


\section{Micro-investment perspective and the potential of the universal basic income}

Teppo Eskelinen ${ }^{1}$ and Johanna Perkiö ${ }^{2}$

In this article, we explore the prospects of Basic Income (BI) as a development policy tool. Our approach is to analyse the $\mathrm{BI}$ as a tool for promoting micro-investments and as a general development policy instrument, thus deliberately departing from the perception of cash transfers as targeted poverty reduction tools. As experiences in testing BI systems in developing country contexts are limited to local and regional experiments in Namibia and India (Haarmann et al., 2009; Haarmann \& Haarmann, 2012; Davala et al., 2015), conclusive assessments about the impacts of the BI cannot be drawn. Therefore, we aim to estimate potential impacts of the BI by synthesising existing knowledge. This estimation will not be quantitative, but rather show likely outcomes of a BI scheme. We will complement existing knowledge by exploring cognate cash transfer policies and other experiences that bear similarity to the BI.

The text will proceed as follows. In the first part, we will sketch some key trends in the geography of global poverty, and how these trends force a reorientation in development policy. We will also make some observations on the dynamics of micro-investment. Subsequently, we will proceed to introduce the idea of the $\mathrm{BI}$, followed by a discussion on the merits of cash transfers and the differences between conditional and unconditional schemes. Finally, we will introduce two recent BI pilot projects and analyse their reported outcomes specifically from the viewpoint of microinvestment. The article finishes with a discussion chapter, in which the findings from preceding chapters are synthesised and assessed.

Keywords: Basic income, inequality, micro-investment, pilot programmes, social cash transfers

\section{Introduction: The context and need for cash transfers}

Development policy has recently been both celebrating its successes and confused. On the traditional criteria of successful development, the world has witnessed tremendous progress. Economic growth in developing countries has been remarkable, and after the long-lasting stagnation

\footnotetext{
${ }^{1}$ Department of Social Sciences and Philosophy, University of Jyväskylä, Finland. Email: teppo.h.i.eskelinen@jyu.fi

${ }^{2}$ School of Social Sciences and Humanities, University of Tampere, Finland. Email: Johanna.Perkio@uta.fi This article has been accepted for publication and undergone full peer review but has not been through the copyediting, typesetting, pagination and proofreading process, which may lead to differences between this version and the Version of Record. Please cite this article as
} doi: 10.1111/dpr.12304

This article is protected by copyright. All rights reserved. 
of the third world economies in the 'lost decades of development' (Easterly, 2001), latest figures show genuine economic catch-up taking place - even though the role of actual development policy is debatable. Yet, new challenges and complexities have emerged, not limited to the fact that a number of economically stagnant countries still exist. Namely the geography of global poverty is undergoing a rapid shift. A few years ago, the world reached a turning point, after which the majority of the extremely poor live in lower-middle-income countries rather than low-income-countries (Alkire et al., 2013; Sumner, 2012a; 2012b). These countries are not acutely short of resources, but rather lack sufficient distributive systems. In such lower-middle-income countries with extremely high income disparities, even small improvements in distributive systems can have a remarkable effect in poverty reduction.

The argument for improving distributive systems gets further support from research. There has recently been also something of a change of perception, when it comes to the relationship between social security and economic growth. Traditionally seen by economists as merely an expenditure and a source of distorted incentives (Fiszbein \& Schady, 2009: 64), social security is emerging as a perspective to investment (Cichon \& Scholz, 2009: 91-92; Dercon, 2011).

Yet until recently, the most common tool for promoting grassroots-level investments in developing countries has been rather an extension of banking: microfinance. Despite some undeniable successes, the results of microcredit have been mixed (Hermes 2011; Westover, 2008). The reason for the shortcomings of microcredit appears to be an insufficient perception of the dynamics of investment. Several studies indicate, that investment requires given psychological conditions in addition to available money (credit, liquidity, etc.). Highly precarious conditions (or perception of high risks) are likely to disincentivise making productive investments which entail risk-taking. For example, poor farmers may adopt safer but lower yielding crop varieties. This contributes to preventing the risk of sliding into absolute destitution, but also averts prospects of higher productivity in the future (Samson, 2009: 123). Case studies point to the fact that unmitigated risk leads to investment behaviour that diminishes the expected returns by about 25 per cent, as the poor invest in safer assets with lower expected returns (Deacon, 2006; quoted Samson, 2009: 131). Other patterns of investment aversion relate to a failure to invest in human capital which could overcome intergenerational poverty, such as education and sufficient nutrition for children (ADB, 2003: 50; Fiszbein \& Schady, 2009: 65), and disinvestment, in other words felt compulsion to sell productive assets, such as livestock, in acute need of liquidity.

This article is protected by copyright. All rights reserved. 
The risk perspective to the dynamics of investment has gained further ground with the theory of 'poor economics': poverty leads to a different form of economic rationality, dominated by a narrow future perspective. Thus, the key to overcome poverty is to overcome this temporal shortsightedness (Banerjee \& Tuflo, 2011). Indeed, micro-investment appears to be to a very large extent conditioned by issues such as the capacity to plan the future, a sense of security, and willingness to take reasonable risks for future gain, rather than mere availability of funds. These conditions are what the very poor often lack, for understandable reasons. Yet the very poor appear to take creating various kinds of 'buffers' against hazards, and see this as an issue of great priority (Barrientos, 2015).

The challenge then is to remove the social risks which disincentivise micro-investments, including investments in human capital. What social transfers indeed at best do is to create an investmentfostering perception of the future amongst the poor. Knowing their basic subsistence is secure removes major day-to-day concerns from poor people and enables them to adopt a longer-term vision. (DFID, 2005: 15). By addressing both permanent stresses (such as bad working conditions) and hazards (job loss, ill health, natural disaster, social instability, crime) (Barrientos, 2015: 3-4), social transfers can provide poor households with some productive capacity a greater confidence to undertake more risky activities, knowing they will have a minimum income to fall back on.

\section{Successes and shortcomings of cash transfer schemes}

Direct cash transfers have lately gained increasing prominence across the developing world (Garcia \& Moore, 2012: 11-12), to the extent that the phenomenon has been called the 'revalorisation of distribution' (Ferguson, 2015: chapter 1). Yet there is a wide diversity in the objectives and design of these schemes, ranging from income transfers proper (social pensions, child grants, family allowances, poverty reduction programmes for the severely poor) to guaranteed employment programmes for working age people (Hanlon et al., 2010). In many occasions, these programmes have proved more cost-efficient and effective in reducing poverty than conventional forms of aid such as food aid, vouchers (Hanlon et al., 2010; Standing, 2012b: 28-34), or subsidies on basic foodstuffs. They also typically manage to avoid the creation of costly project management bureaucracies often seen in conventional development interventions, as well as the harmful collateral effects on local markets and agriculture, which characterise many subsidy schemes.

The concept of Social Cash Transfers (SCT) is typically used to denote all kinds of cash transfers which involve some selectivity. The method of selection of recipients determines the type of SCT. The two

This article is protected by copyright. All rights reserved. 
most articulate categories are conditional cash transfers and targeted cash transfers. These categories can be also overlapping. In conditional models, transfers are conditioned on given actions or activities by the recipients, such as enrolling children at school or using given health care services. Both conditional and unconditional systems typically involve targeting of benefits either to extremely poor households with labour constrains (Asfav et al., 2014: 1172; Schubert \& Slater, 2010: 571-572), or more typically in the case of conditional systems, to the poor households with school-age children (ibid.). Yet, in some of the existing minimum pension schemes and universal child benefits targeting is based only on age, which brings them very close to the idea of basic income.

Among the best known SCT schemes are Brazil's Bolsa Familia (a form of guaranteed minimum income for poor families conditioned on children's school attendance), Mexico's Oportunidades (a cash transfer programme for individuals living in conditions of extreme poverty with a special focus on the empowerment of women), India's National Rural Employment Guarantee (a public employment programme) and South Africa's Old Age Pension and Child Support Grants (large programmes with universalistic character).

SCT programmes have proved successful in alleviating extreme poverty, improving nutritional and health status of the recipients, and increasing school attendance rates (Lomelí, 2008; Todd et al., 2010; Gertler et al., 2012; Asfav et al., 2014). Further, studies have shown that in rural areas cash transfer programmes have contributed to income generating activities that can provide a higher long-term living standard for the beneficiary households, increase in livestock ownership and investment in agricultural assets such as crops, land or technology, and sometimes also in nonagricultural productive assets and entrepreneurial activities (Gilligan et al., 2009; Todd et al., 2010; Soares, Ribas \& Hirata, 2010; Covarrubias et al., 2012; Gertler et al., 2012; Asfav et al., 2014).

Yet on the downside, given shortcomings can generally be identified in most conditional and/or targeted programmes (Standing, 2012a; 2012b; UNRISD, 2010: 136-158). Evidence of four distinct categories of problems can be found.

First, targeting often misses the very bottom stratum. Public services are typically 'targeted' in the sense that services react to need, but practically in many developing countries, public services and public infrastructure do not reach the very poor, as they are concentrated in low-middle income and wealthier areas (Fiszbein \& Schady, 2009: 64). 'Targeting the poor' can at worst mean that this phenomenon occurs also in SCT programmes: the moderately poor rather than the destitute reap

This article is protected by copyright. All rights reserved. 
the benefits from the programmes, as the ones on the bottom of the income pyramid often lack the means to access or make use of these programmes (Copestake at al., 2001; Morduch, 1998).

Second, means-testing unavoidably creates somewhat arbitrary categories. Sharply distinct categories of the eligible and ineligible are created, even though the life situations of people on both sides of the eligibility divide are typically very similar. A similar phenomenon has been seen in global poverty measurements: while globally hundreds of millions of people have ascended above the lowest poverty line, these people tend to lump just above this threshold (World Bank, 2017b) ${ }^{3}$. Further, incomes amongst the very poor tend to fluctuate and sometimes are only partially documented ${ }^{4}$. This, together with the backwards-looking nature of means-testing (focusing on 'yesterday's rather than tomorrows poverty'), emphasises the arbitrary nature of poverty lines. Economic insecurity and an increasing amount of irregular and non-standard employment characterise the life of considerable part of the working age population, especially in developing countries (ILO, 2013; Ghose, Majid \& Ernst, 2008: 70-72). A very likely result of these problems are exclusion errors. The problem of sharp distinction between the eligible and the ineligible is particularly acute in income-tested or labour-market-status tested systems and in cases of existence of several overlapping schemes with different eligibility criteria.

Third, regardless of the actual criteria of targeting ${ }^{5}$, there is a constant need to monitor the recipients' economic status, requiring bureaucratic monitoring systems for performing the meanstesting. The administration process required for carrying out the eligibility assessments is costly and potentially suppressing. Eligibility assessments often entail paternalistic control over the recipients and enhance the discretionary power of authorities. Further, attention has been paid to the low level of institutionalisation in developing countries as a particular challenge for SCT programmes (Barrientos, 2013: 25, 29-30), which can lead to misuse and corruption. The eligibility assessments allow in some contexts the payments of SCTs to be captured by local elites in clientelist relations. Further, continuous eligibility assessments are sometimes seen to foster the segmentation of social protection programmes and the separation of the poor from other social classes. Sometimes means-

\footnotetext{
${ }^{3}$ In low-income countries, poverty on PPP $\$ 1,9$ poverty line has decreased from 284 to 279 million between 2005-2013 (period of data availability) and increased from 329 to 435 million on PPP3,1 poverty line. The respective figures for lower middle income countries are 772 to 464 (PPP\$1,9) and 1592 to 1316 (PPP\$3,1). The fact that poverty reduction is less rapid when measured on a higher poverty line, indicates that people liberated from poverty on the $\$ P P P 1,9$ definition of poverty tend to concentrate between the two poverty lines.

${ }^{4}$ These problems have been attempted to be solved, with some success, by using so called proxy indicators of social deprivation, such as quality of housing or type of economic activity the households are engaged in.

5 'Targeted' can mean targeting on thegrounds of labour-market status, social status, place of residence, etc., and the method of targeting of course is an important determinant in the results achieved. Yet some points can be made about targeting in general.
}

This article is protected by copyright. All rights reserved. 
testing also requires considerable input from the recipients, in the form of obtaining a number of documents from different authorities, which consumes potentially large amounts of time, and creates further vulnerability to corruption (for an example, see DWC, 2011).

Fourth, means-testing can create problematic incentives, because of the insensitivity towards the realities of flexible labour. Means-tested schemes may result in situations in which there are no incentives to improve one's level of income by employment or entrepreneurship, as this would trigger the loss of benefits. Also, means-testing has direct effects on people's incentives to join the workforce: often, an additional income enables people to seek employment (Samson, 2005: 134135), while disinventivising grants rather cause people to leave the workforce (ibid., 138). The risk of being excluded is also related to temporary change of conditions, or erroneous exclusion.

\section{Basic income as social policy}

While the severity of these issues varies between different programmes, they force a reconsideration of the merits of conditionality and targeting. Interestingly enough, there is indicative evidence that the positive results of targeted and/or conditional programmes can result from the cash transfer itself rather than the attached conditions. For instance, Martin Ravallion found that targeting was not a factor explaining the success or failure of the antipoverty programmes in China (Ravallion 2009). Further, the DFID notes, that typically the goals sought with conditionalities would be attained even without it. For instance, cash transfers do not need to be made conditional on school attendance to have a positive impact on children's education. (DFID, 2005: 14). This is the context in which $\mathrm{BI}$ emerges as a serious policy option. While paying a given regular grant (BI) to the whole population will raise issues of supporting those without need, it can nevertheless prove more costefficient, if it will perform better in unleashing economic and social potential in its recipients by undoing paternalistic control, arbitrary exclusion and poverty lines, as well as recognising the flexibility of labour.

The $\mathrm{Bl}$ indeed deviates from other SCT systems by the virtue of its universality. As the standard definition goes, $\mathrm{BI}$ is 'an income unconditionally paid to all on an individual basis, without means test or work requirement' (Van Parijs, 1992: 3). The idea is to give everyone 'a modest, yet unconditional income, and let them top it up at will with income from other sources' (Van Parijs 2004, 7). As such, it comprises 'a guaranteed income floor below which no eligible individual is expected to fall' (De Wispelaere, 2015: 15). It is paid irrespective of individual background circumstances such as labour

This article is protected by copyright. All rights reserved. 
market or family status (Ibid.), the idea being that the better-off part of the population contributes more to the financing of the system than the less well-off.

Offering a 'Painean' alternative to the contemporary Bismarckean and Beveridgean welfare states (Noguera, 2001; De Wispelaere, 2015: 16), BI differs from Social Cash Transfers in some important respects. First, by definition, $\mathrm{Bl}$ is universal, i.e. it covers the entire population of a given country/area either on basis of residency or citizenship. Thus, it adheres to and extends the principle of universalism, which has historically shaped the welfare policies particularly in the areas of education and health services and insurances, as well as the cash allowances for families and old-age population (Titmuss, 2014: 38). The central aim of universalist policies has been to make services 'available and accessible to the whole population in such ways as would not involve users in any humiliating loss of status, dignity or self-respect' (ibid.). Nor should there be a 'sense of inferiority, pauperism, shame or stigma' (...) or 'attribution that one was being or becoming a 'public burden" (ibid.). Selectivity, as opposed to universalism, has often characterised the social security of the working age population in the form of 'principles and mechanisms that are employed to decide on eligibility' (De Wispelaere, 2015: 50). Those principles and mechanisms may range from gaining eligibility through work history to submitting to a means-test and behavioral control in order to receive last-resort social assistance. Selectivity, however, should not be confused with targeting, as there can be 'targeting within universalism' (Skocpol, 1991).

Second, whereas most welfare policies come with some conditions, Bl is purportedly unconditional or 'at the very least only employs conditions that do not violate the programme's inclusiveness' (De Wispelaere, 2015: 52). Jochen Clasen and Daniel Clegg (2007) distinguish following three types of conditionality: (1) conditions of category (membership of a politically defined social support category), (2) conditions of circumstance (eligibility or entitlement defined for example by meanstest), and (3) conditions of conduct (behavioral requirements as a condition upon receipt of support). In the existing welfare systems, most benefits (granted on the grounds of unemployment, disability or some other reason) apply the conditions of category, and apart from disabled or old-age population, also conditions of conduct (such as being available for paid employment). The last-resort social assistance systems, instead, are typically based on means-test (monitoring the recipient's economic situation), yet receiving social assistance does not necessarily imply conditions of conduct.

Third, BI is individual. Individuality means that the grant should be allocated directly to each individual instead of a family or household (De Wispelaere, 2015: 51-52). There is, however, a

This article is protected by copyright. All rights reserved. 
dispute on whether the level of individual BI should be adjusted to a household situation or even granted on a household basis (ibid.). As a strictly individual payment the scheme would avoid questions arising with respect to the appropriate definition of a household and its composition, and consequently, arbitrary discrimination of some life-style choices (ibid.). In turn, being set on a uniform level for all, those sharing the household expenses would end up better-off relative to the single individuals.

An important feature of $\mathrm{Bl}$ is the aim to transcend existing categories of social protection, such as 'unemployed', 'student', 'disabled', or 'parent', and guarantee a minimum income regardless of the life conditions or labour market status of the recipient. This is increasingly important, as labour market conditions become increasingly precarious and the divide between work and non-work, education or entrepreneurship becomes increasingly elusive (Standing, 2011). Yet the BI discourse has, to a large extent, been conceptually engaged to the post-industrial and 'cognitive capitalism' framework ${ }^{6}$. However, many of the arguments in favour of the BI in the post-industrial context would also be applicable, or even be more to the point, in the context of the developing world. A large informal sector and the blurring boundary between working and not working, as well as the need to combine labour income with social transfers and improve the bargaining power of the most precarious workers are even more topical in low and middle income countries than they are in the developed welfare states.

\section{The BI pilot programmes}

The two systematically implemented BI pilot programmes in developing countries have been carried out in India and Namibia, both high-inequality countries with strong economic growth. In Namibia, 62-82 per cent of the population (depending on definition) live below the national poverty line (around 20 per cent if the lower World Bank global poverty line is applied), while the country itself is classified as an 'upper-middle income' country (Jauch, 2015: 339; World Bank, 2017a). In India, the official poverty figures stand at about 30 per cent on the national poverty line (GIPC 2014).

The experiments in both countries were conducted in rural areas and on external funding, without government involvement. The Namibian experiment took place in only one village, whereas the Indian experiments covered several villages in the state of Madhya Pradesh. The evaluation methods

\footnotetext{
${ }^{6}$ Some seminal discussions have been seen in South Africa (Seekings \& Matison, 2012; Barchiesi, 2008) and Brazil (Suplicy 2002). The discussion in India will be referred to in the discussion chapter.
}

This article is protected by copyright. All rights reserved. 
in both experiments consisted of surveys, case studies and interviews. Interviews were conducted before, during and after the experiment (Haarmann et al., 2009; Haarmann \& Haarmann, 2012; Davala et al., 2015). It needs to be noted, though, that the approach of the Namibian experiment has received criticism. While it has been called 'one of the best documented and promoted socioeconomic projects in Namibia' (Klocke-Daffa, 2012: 5), it has also been criticised for failing to live up to good academic standard, because of the small sample given the size of Otijvero, lack of comparison data in the form of a control group, the anecdotal status of some evidence, and general imprecision (Osterkamp, 2013; Kaufmann, 2010).

In Namibia, the experiment ran for two years in 2008-2009, organised by the Basic Income Grant (BIG) Coalition ${ }^{7}$ which consists of several $\mathrm{NGOs}^{8}$. Funds were raised through voluntary contributions from individual and organisational supporters in Namibia and abroad. The experiment took place in Otjivero-Omitara, a low-income rural area about 100 kilometers from the capital Windhoek. The village was characterised by high unemployment and high prevalence of extreme poverty. A total of 930 inhabitants (including children) received a monthly grant of 100 Namibian Dollars each (about 12.40 USD/8.60 €) with no strings attached. Those eligible for the universal old age pension payments $(60+$ years $)$ were excluded.

In India, the rural BI pilots in Madhya Pradesh from 2011 to 2013 were financed by UNICEF and implemented by the Self-Employed Women's Association (SEWA). The evaluation was carried out by an independent research team. In Madhya Pradesh, the initial project covered 20 villages. In eight villages, the BI grant was paid universally, while the remaining 12 villages were observed as 'control villages'. A second phase of the project was carried out in two similar indigenous villages, one being assigned as test village and the other as control village. Initially, each adult individual in the test villages received a monthly unconditional grant of 200 Rupees (about 3.75 USD/2.80 €). Each child under the age of 14 received half of that amount. After one year, the amounts were raised by 100 Rupees for adults and 50 Rupees for children. The amount was equivalent to about 20 to $30 \%$ of household income of the lower-income families. A total of about 6000 individuals in eight villages received the BI grants for 12 to 17 months. The control villages included, the surveys covered over 15000 individuals.

\footnotetext{
${ }^{7}$ http://bignam.org/

${ }^{8}$ The Council of Churches (CCN), the National Union of Namibian Workers (NUNW), the Namibian NGO Forum (Nangof), the National Youth Council (NYC) and the Namibian Network of AIDS Service Organisations (Nananso).
}

This article is protected by copyright. All rights reserved. 


\section{A meta-analysis of key findings}

For the purposes of this article, we analysed the available data from the two pilot projects, along with data from some similar projects. Our specific interest was to study this data from the microinvestment viewpoint. While it has been documented earlier that both experiments made a significant positive contribution to for instance the food sufficiency and variation of diets in the regions, we focused on the investment effect behind these admirable social outcomes.

Generally, key findings from the projects were strikingly similar with each other and corresponded with main findings from existing cash-transfer programmes, with somewhat more pronounced positive outcomes (Haarmann et al., 2009; Davala et al., 2015). With regard to investment, four main categories of outcomes could be identified: effects of the BI pilots on labour, behavioural impacts, psychological impacts, and investment in human capital.

As for labour, the BI has often been associated with economic impacts which derive from removing barriers to employment. These include economic incentives as well as practical barriers such as physical access to labour markets. Evaluations of the BI pilots indeed consistently document an increase in the amount of labour (Davala et al., 2015: 139), contrary to some prejudices according to which the BI will result in negative behavioural changes or 'laziness' (Jauch, 2015: 343, 345). In Namibia, the BI resulted especially in an increase of own-account work on small farms, increasing the labour force participation rate from 44 to 55 per cent. In India, the BI resulted in general increase in working days, especially in own-account labour, as well as diversification of household income (Davala et al., 2015: 139-147).

Yet it is unclear, to what extent increased labour time is a cause for celebration: much of the labour carried out by the poorest is dull and underpaid. Indeed, a more important observation was a qualitative change in labour. In addition to the diversification of forms of income, there was a clear shift from wage labour to own-account work observed in the Indian BI pilot (Davala et al., 2015: 14344). The issue at stake is not only shift of labour type, but significantly an improvement of the bargaining position in wage labour. Further, there was a slight decrease of 'over-employment' (ibid., 143), which means that less time was used in waiting for labour opportunities (ibid., 144). Crucially, the improvement of the bargaining position and especially diversification of income sources also provide improved buffers against various social hazards.

This article is protected by copyright. All rights reserved. 
Second, the behavioural impacts were marked, particularly from the investment perspective. A recurring observation in the $\mathrm{BI}$ pilots was, that part of the additional income was invested in incomegenerating activities (For Namibia, see Haarmann et al., 2009: 73). Also, increased investment in livestock ownership and agricultural implements, as well as producer goods such as sewing machines, seeds or fertilisers, was observed (Davala et al., 2015: 147-153). The evaluators in Namibia noted that personal incomes of the recipients increased substantially more than the actual grants paid out (from NAD 118 to 152 monthly). The main source of the income growth was selfemployment (Haarmann et al., 2009: 72).

In Namibia, it was noted that the BI grant enabled recipients to increase their productive income, particularly through starting their own small businesses, such as brick-making, baking bread and dress-making. The BIG also increased the purchasing power of the inhabitants, thereby creating a market for the products of the new businesses. (Haarmann et al., 2009: 73-74). An increase was also observed in ownership of livestock and poultry. According to the coalition carrying out the pilot project, the project demonstrates that $\mathrm{BI}$ can 'kick-start local economic processes and thereby shift buying power and investment capital into the rural areas' (Basic Income Grant Coalition, 2015).

In India, households receiving cash grants were three times more likely to start a new business or production activity than control group households. The number of livestock and investments in agricultural implements increased, contributing to better agricultural yield, improved nutrition, as well as savings and insurance. Many families used cash grants to buy small items for production, such as sewing machines or seeds and fertilisers to increase the productivity of land (Davala et al., 2015: $55,149)$. According to the interviewed BI recipients, before the pilot programme exactly the lack of liquidity had prevented the purchase of livestock (Davala et al., 2015: 148). There was also clear evidence of pooling money for future productive assets (ibid., 147-148).

Third, these behavioural changes appear to be related to psychological impacts of the scheme. As was noted when discussing microfinance, the availability of money combined with a sense of security is what eventually determines the occurrence of micro-investment. Indeed, observed results were often expressed with a psychological vocabulary, such as: 'the BIG ignited hope' (Haarmann \& Haarmann, 2009: 14; Jauch, 2015: 342). This appears to be seen by many of the advocates of the BI as merely a line for 'selling' the BI concept, but might turn out to be a key impact of the BI.

Fourth, another markedly increased form of investment was investment in human capital. A clear

This article is protected by copyright. All rights reserved. 
increase in the school attendance of children was noted (also pointing again to the negligible impacts of conditioning cash transfers on school attendance). A further locally highly important set of investments was observed in inputs to health-enhancing infrastructure, such as constructing latrines and upgrading dwellings and water sources. All these contribute to people's full and healthy functioning capacity, which extends also to productive life.

Also, the outcomes of other programmes, which are not BI proper but close enough to give indicative results regarding the $\mathrm{BI}$, have produced similar results. In the Givedirectly programme in Kenya, randomly selected poor households were granted unconditionally either a large one time lump-sum or a smaller monthly transfer for over 9 months. The transfers generated productive investments to non-agricultural micro-entrepreneurial activities, along with a significant reduction of the stress hormone cortisol (Haushofer\& Shapiro, 2013), implicating improved prospects for not only wellbeing, but also long-term planning. In Uganda, the government ran a transfer programme for poor and largely unemployed youth aged between 16 and 35 . The grants (lump-sum payments corresponding roughly an annual income) were to be applied as start-up capital for enterprises and to be invested in vocational training and business assets, yet their usage was not controlled afterwards. The programme was found to yield high economic returns two or four years after the grant payments (Blattman et al., 2013).

\section{Discussion and conclusions}

Throughout this text, we have focused on investment as a perspective to cash transfers. This perspective emphasises the merits of SCT systems particularly in comparison to microlending, yet it appears that the $\mathrm{BI}$ schemes could produce similar benefits but without the shortcomings associated with SCTs.

What has been noted, though, is that the concept of 'investment' has several potential meanings. Importantly, it needs to be understood in the broadest possible sense, meaning any future-oriented input for greater productivity or other gain, while often it is reserved to mean only large-scale FDI. Much of micro-investment activity is hardly even discernible for an outsider, and is only recognised as 'community development' (Davala et al., 2015: 137). Yet it can represent crucial improvements from individual perspective.

To be analytical, micro-investment can mean, first, enabling other activities. For instance,

This article is protected by copyright. All rights reserved. 
constructing and repairing one's house is clearly for many people a form of investment activity (Hulme \& Moore, 2007). It significantly reduces the probability of a number of hazards, such as weather damage to the house (requiring money to fix it), ill-health due to improper shelter, and being subject to crime. In the Indian BI pilot, constructing firm houses was a very common activity of the $\mathrm{BI}$ recipients, allowing the recipients to live free from constant need of labour input in renovation. Second, it can mean a steady state of avoiding disinvestment, in other words being free from compulsion to sell productive assets when a dire need for liquidity occurs. Need for liquidity can also result in an inability to delay sales of produce, thereby obtaining a worse price. Third, investment can mean inputs to increase efficiency. For instance, in the case of buying livestock or small machinery, the mode of production remains but with an increased output relative to labour time.

Fourth, investment can be disruptive in the sense of changing the mode of productive activity. For instance, it is a different issue to get a better crop than to move away from agriculture into higherproductivity employment. The investment perspective to the $\mathrm{Bl}$ appears promising not only in the general sense of efficiency, but also in disruptive sense. As noted, there was a marked shift in the change of labour type observed. A similar impact has been observed in some SCT programmes: for example, in Paraguay, an SCT grant led to an increase in the reservation wage of temporary workers, implying increase of productivity as there was less pressure to accept low-quality 'casual jobs' (Soares, Ribas \& Hirata, 2008). Further on the macro-level, there is an observed strong positive correlation between social expenditure (per capita of the population) and labour productivity (GDP per hour worked) (Cichon \& Scholz, 2009: 93). The promising aspects of the BI relate to the simultaneous occurrence of these several meanings of investment, with an emphasis on change of labour type.

Yet as the BI has been tested only within small-scale pilot programmes, some key challenges remain. Several problems of $\mathrm{BI}$ can only be addressed when the scheme is established country-wide. At least three further complexities or open questions exist: acceptance and diffusion of the policy idea, replacement and funding.

What will come out of the BI when it is to be institutionalised? Will there be resistance towards it, and how this resistance will affect the eventual form of the BI? Yet noteworthily, the $\mathrm{Bl}$ is no more devoid a presence in the realm of political discourse. In India, where the larger and more systematic $\mathrm{BI}$ pilot programme took place, the $\mathrm{BI}$ appears to be gaining ground as several prominent politicians

This article is protected by copyright. All rights reserved. 
have recently promoted the approach (Gandhi, 2016; Panda, 2016). The BI also appears to be under serious consideration within the government (McFarland, 2016a; 2016b). Yet undeniably further research is needed on the ideational aspect of BI promotion (von Gliszczynski 2015).

Regarding the acceptance of the $\mathrm{Bl}$, there are two points worth noting. First, a significant but overlooked finding in the Indian BI pilot was that investment activity took place amongst all castes (Davala et al., 2015: 149), pointing to the potential of wider acceptance. Second, there are reasons to believe that the political and ideological aspects at least in their current form derive more from donor preferences rather than from political struggle 'on the ground'. As Armando Barrientos has argued, preference for conditionality derives from American political culture in which the idea of the poor needing supervision is taken for granted, to the extent that even well-meaning scholars tend to assume that poverty is largely upheld by 'persistently misguided beliefs' of the poor (Hulme, Hanlon \& Barrientos, 2014). For its part, European political culture tends to assume the necessity of targeting, which leads most European donors to see cash transfers exclusively as an antipoverty measure rather than a wider rights-based idea, a matter of economic rationale or a development strategy (ibid.). Thus, as far as development policy is evidence-based, observations of policy outcomes and systematic estimations of likely conduct change in different systems might change the diffusion prospects.

What existing social security or transfer systems would the BI replace? Here, it suffices to note two issues. First, the $\mathrm{BI}$ is an umbrella concept which allows variation. We assume that particular models would be designed in local policy processes to suit the respective context. The key question is, whether the general idea of 'free money to everyone' is feasible as social policy and as a strategy of growth-from-below. Second, the very point of emphasising the suitability of the BI to highly unequal countries is, that even relatively small payments from the government budget are sufficient in providing amounts of money which are considerable from the perspective of the poor, without causing excessive 'mistargeting' as the wealthier part of the population tends to be small.

How will the BI be financed? If financing would be, at least temporarily, available through development funding, the problem of garnering funds becomes locally less acute, although necessary to face on the long run. The proposals on funding a BI range from income taxation to consumer or corporate taxes, resource or wealth taxes, financial market taxes, as well as novel ideas such as central bank financing or crypto-currencies (De Wispelaere, 2015: 59-60). One widely discussed alternative is the use of resource dividends as a funding source, following the example of

This article is protected by copyright. All rights reserved. 
the oil revenue based Alaska Permanent Dividend Fund (Ibid.). On the other hand, if the $\mathrm{BI}$ is assumed to replace existing social security systems, funding ceases to be an issue. The Namibian BIG coalition estimated that a universal national BIG of NAD100 would cost around 5 per cent of the national budget (Jauch, 2015: 341), while the already existing cash transfer systems in the country costs 6 per cent (Levine, van der Berg \& Yu, 2009). In India, it was estimated that the funds spent in current subsidy schemes and their administration could be alternatively used to fund a $\mathrm{Bl}$, the sum of which would exceed the rural poverty line (Davala et al., 2015: 206-208).

It needs to be remembered that the BI does not constitute a single ideal, but rather a family of policies that harbours 'many faces' in terms of design, aims, and expected social as well as political effects (De Wispelaere, 2015: 49). Consequently, the potential impacts, for instance on income distribution, poverty, or people's labour market behavior, depend to a large extent on the design of a particular BI model and the financing approach. Yet the bottom line of the argument for the $\mathrm{BI}$ is the mounting evidence that the poor seem to make sensible decisions concerning their well-being, also with a longer temporal perspective given that they have a reliable material baseline guarantee. The BI pilots indicate strong results exactly in regard to the micro-investment effect. There are all reasons to assume that a country-wide BI would be efficient in creating a secured perception of the future, along with a diversification of buffers. The synthesis of existing research presented in this article shows strong reasons to continue diffusing the BI concept to eventually create forms of social security devoid of the shortcomings associated to means-testing.

first submitted March 2017

final draft accepted June 2017

\section{References}

ADB (Asian Development Bank) (2003). Education: our framework, policies and strategies. Manila: Asian Development Bank.

Alkire, S., Roche, J. M., \& Sumner, A. (2013). Where do the multi-dimensionally poor live? OPHI Working Paper. Oxford: OPHI.

Banerjee, A., \& Duflo, E. (2011). Poor economics. A radical rethinking of the way to fight global poverty. New York, NY: PublicAffairs \& Perseus Books.

Barchiesi, F. (2008). South African debates on the basic income grant. Wage labour and the postapartheid social policy. Journal of Southern African studies, 33, 561-575. http://dx.doi.org/10.1080/03057070701475575.

Barrientos, A. (2013). Social protection for poverty reduction: Approaches, effectiveness and

This article is protected by copyright. All rights reserved. 
challenges. In A. Barrientos, \& K. B. M. K. C. Pfiederer (eds.), Social protection in developing countries: Reforming systems (pp. 24-32). London: Routledge.

Barrientos, A. (2015). Assessing the insurance role of microsavings. In A. Barrientos, D. Hulme, K. Moore, N. Islam, (ed.) \& R. Vos (ed.), Financing for overcoming economic insecurity (pp. 149-179). New York: Bloomsbury Academic.

Basic Income Grant Coalition (2015). A call for the national implementation of the Basic Income Grant (BIG) in Namibia. Press release, 25 Jun 2015. Retrieved from http://www.bignam.org/Publications/Press release July 2015.pdf.

Blattman, C., Fiala, N., \& Martinez, S. (2013). The economic and social return to cash transfers: Evidence from a Ugandan Aid Program. CEGA Working Paper. Retrieved from http://cega.berkeley.edu/assets/cega events/53/WGAPE Sp2013 Blattman.pdf.

Clasen, J., \& Clegg, J. (2007). Levels and levers of conditionality: Measuring change within welfare states. In J. Clasen, N. A. \& Siegel (eds.), Investigating Welfare State Change. The 'Dependent Variable Problem' in Comparative Analysis (pp. 166-197). Cheltenham \& Northampton: Edgar Elgar.

Cichon, M., \& Scholz, W. (2009). Social security, social impact and economic performance: A farewell to three famous myths. In P. Townsend (ed.), Building decent societies: Rethinking the role of social security in state building (pp. 80-98). Basingstoke: Palgrave MacMillan.

Covarrubias, K., Davis, B., \& Winters, P. (2012). From protection to production: Productive impacts of the Malawi social cash transfer scheme. Journal of Development Effectiveness, 4, 50-77. http://dx.doi.org/10.1080/19439342.2011.641995.

Davala, S., Jhabvala, R., Standing G., \& Mehta, S. K. (2015). Basic income: a transformative policy for India. London: Bloomsbury.

Dercon, S. (2011). Social protection, efficiency and growth. CSAE Working Paper Series 2011-17, Centre for the Study of African Economies, University of Oxford.

De Wispelaere, J. (2015). An income of one's own? The political analysis of universal basic income. Academic dissertation. Tampere: University of Tampere. Retrieved from http://tampub.uta.fi/handle/10024/98162.

DFID (Department for International Development) (2005). Social Transfers and Chronic Poverty: Emerging Evidence and the Challenge Ahead. DFID Practice Paper. London: DFID.

Easterly, W. (2001). The lost decades: Developing countries' stagnation in spite of policy reform 1980-1998. Journal of Economic Growth, 6, 135-157. DOI: 10.1023/A:1011378507540.

Ferguson, J. (2015). Give a man a fish. Reflections on the new politics of distribution. Durham and London: Duke University press.

Fiszbein, A., \& Schady, N. (2009). Conditional cash transfers. Reducing present and future poverty. Washington DC: World Bank.

Gandhi, F. V. (2016). Why we need to talk about a basic income. The Hindu 30.6.2016. Retrieved from http://www.thehindu.com/opinion/columns/Why-we-need-to-talk-about-a-basicincome/article14463390.ece

This article is protected by copyright. All rights reserved. 
Garcia, M., \& Moore, C. (2012). The cash dividend. The rise of cash transfer programs in sub-Saharan Africa. Washington DC: World Bank.

Gertler, P., Martinez, S., \& Rubio-Codina, M. (2012). Investing cash transfers to raise long-term living standards. American Economic Journal: Applied Economics, 4, 164-192. DOI: 10.1257/app.4.1.164.

Ghose, A., Majid, N., \& Ernst, C. (2008). The global employment challenge. New Delhi: ILO, Geneva \& Academic Foundation.

Gilligan, D., Hoddinott, J., \& Taffesse, A. (2009). The impact of Ethiopia's productive safety net program and its linkages. Journal of Development Studies, 45, 1684- 1706.

http://dx.doi.org/10.1080/00220380902935907.

GIPC (Government of India planning commission) (2014). Rangarajan report on poverty. New Delhi: Government of India.

von Gliszczynski, M. (2015). Cash transfers and basic social protection: Towards a development revolution? Basingstoke: Palgrave MacMillan.

Haarmann C., Haarmann D., Jauch H., Shindondola-Mote H., Nattrass, N., van Niekerk, I., \& Samson, M. (2009). Making the difference! The BIG in Namibia. Basic Income Grant Pilot Project. Windhoek: Basic Income Grant Coalition, Assessment Report. Retrieved from http://www.bignam.org/Publications/BIG Assessment report 08b.pdf.

Haarmann, C., \& Haarmann, D. (2012). Piloting basic income in Namibia - Critical reflections on the process and possible lessons. A paper presented in BIEN2012 Congress in Munich. Retrieved from http://www.bien2012.org/sites/default/files/paper 196 en.pdf.

Haarmann, C., \& Haarmann, D. (2012). Namibia: Seeing the sun rise - The realities and hopes of the Basic Income Grant Pilot Project. In M. C. Murray, \& C. Pateman (eds.), Basic income worldwide. Horizons of reform (pp. 33-58). Hampshire \& New York: Palgrave MacMillan.

Hanlon, J., Barrientos, A., \& Hulme, D. (2010). Just give money to the poor: The development revolution from the Global South. Sterling, VA: Kumarian Press.

Haushofer, J., \& Shapiro, J. (2013). Household response to income changes: Evidence from an unconditional cash transfer program in Kenya. Retrieved from https://www.princeton.edu/ joha/publications/Haushofer Shapiro UCT 2013.pdf

Hermes, N. (2011). Microfinance. Its impact, outreach and sustainability. World Development, 39 (6), 875-881.

Hulme, D.; Hanlon, A. \& Barrientos, A., (2014). Social protection, marginality and extreme poverty: Just give money to the poor? In von Braun, J. (ed.), \& Gatzweiler, F. W. (ed.), Marginality: Addressing the nexus of poverty, exclusion and ecology (pp. 315-329). London and New York: Springer Verlag.

ILO (International Labour Organisation) (2013). Global employment trends for youth. A generation at risk. Geneva: ILO.

Jauch, H. (2015). The rise and fall of the Basic Income Grant Campaign: Lessons from Namibia, Global Labour Journal, 6, 336-350. DOI: https://doi.org/10.15173/glj.v6i3.2367.

Kaufmann, J. (2010). BIG hopes, BIG questions: Namibia's Basic Income Grant. Journal of Civil Society

This article is protected by copyright. All rights reserved. 
and Social Transformation, 1, 38-47. Retrieved from

https://www.maxwell.syr.edu/uploadedFiles/moynihan/tngo/BIG\%20Hopes,\%20BIG\%20Questions\% 20Namibia's\%20Basic\%20Income\%20Grant.pdf.

Klocke-Daffa, S. (2012). Is BIG big enough? Basic Income grant in Namibia. An anthropological enquiry. University of Tübingen report. Retrieved from https://publikationen.uni-

tuebingen.de/xmlui/bitstream/handle/10900/46965/pdf/Rport 2012 Is BIG big enough end.pdf? sequence $=1$

Levine, S., van der Berg, S., \& Yu, D. (2009). Measuring the impact of social cash transfers on poverty and inequality in Namibia. Stellenbosch economic working paper 25/09. Stellenbosch: Department of economics and Bureau for economic research, University of Stellenbosch.

Lomelí, E. V. (2008). Conditional Cash Transfers as Social Policy in Latin America: An Assessment of their Contributions and Limitations. Annu. Rev. Sociol. 2008, 34, 475-99. DOI:

10.1146/annurev.soc.34.040507.134537.

McFarland, K. (2016a). India: Government continues to show interest in UBI. Basic Income Earth Network. Retrieved from http://basicincome.org/news/2016/10/india-government-continues-toshow-interest-in-universal-basic-income/

McFarland, K. (2016b). India: Government economic survey to address UBI. Basic Income Earth Network. Retrieved from http://basicincome.org/news/2016/09/india-government-economicsurvey-address-ubi/

Noguera, J. A. (2001). Some Prospects for a Basic Income Scheme in Spain. South European Society and Politics, 6(3), 83-102. http://dx.doi.org/10.1080/714004953.

Osterkamp, R. (2013). The Basic Income Grant Pilot Project in Namibia: A Critical Assessment. Basic Income Studies, 8, 71-91. https://doi.org/10.1515/bis-2012-0007

Panda, B. (2016). Cash to all citizens: Universal basic income could actually work better in India than in rich countries. The times of India 27.10.2016. Retrieved from

http://blogs.timesofindia.indiatimes.com/toi-edit-page/cash-to-all-citizens-universal-basic-incomecould-actually-work-better-in-india-than-in-rich-countries/

Ravallion, M. (2009). How important is targeting to the success of an antipoverty program? World Bank research observer, 24 (2), 205-231.

Samson, M. (2005). Fieldwork notes from the EPRI Western Cape Household Survey. Cape Town: Economic Policy Research Institute.

Samson, M. (2009). The impact of social transfers on growth, development, poverty and inequality in developing countries. In P. Townsend (ed.), Building decent societies: Rethinking the role of social security in state building (pp. 122-150). Basingstoke: Palgrave MacMillan.

Schubert, B., \& Slater, R. (2010). Social cash transfers in low-income African countries: Conditional or unconditional? Journal of Development Studies, 46, 14-38. doi:10.1111/j.1467-7679.2006.00348.x

Seekings, J., \& Matisonn, H. (2012). South Africa: The continuing politics of basic income. In M. C. Murray, \& C. Pateman (eds.), Basic income worldwide. Horizons of reform (pp. 128-150). Hampshire \& New York: Palgrave MacMillan.

This article is protected by copyright. All rights reserved. 
Skocpol, T. (1991). Targeting within universalism: Politically viable policies to combat poverty in the United States. In C. Jencks, \& P. E. Peterson (eds.), The urban underclass (pp. 411-36). Washington, DC: The Brookings Institution.

Soares, F. V., Ribas, R. P., \& Hirata, G. I. (2008). Achievements and shortfalls of conditional cash transfers: Impact evaluation of Paraguay's Tekoporã Programme. IPC-IG Publications 3. Brasilia: International Policy Centre for Inclusive Growth.

Soares, F. V., Ribas, R. P., \& Hirata, G. I. (2010). The impact evaluation of a rural CCT programme on outcomes beyond health and education. Journal of Development Effectiveness, 2, 138-157.

http://dx.doi.org/10.1080/19439341003624433

Sumner, A. (2012a). Where do the poor live? World Development, 40, 865-77.

https://doi.org/10.1016/i.worlddev.2011.09.007

Sumner, A. (2012b). From deprivation to distribution: Is global poverty becoming a matter of national inequality? IDS Working Paper. Brighton: IDS.

Suplicy, E. (2002). From a minimum income to a basic income in Brazil. USBIG discussion paper no.34, April 2002.

Standing, G. (2011) The Precariat: The new dangerous class. London and New York: Bloomsbury Academic.

Standing, G. (2012a). Basic income pilot schemes: Seventeen design and evaluation imperatives. In D. Jacobi \& W. Strengmann-Kuhn (eds.), Wege zum Grundeinkommen (pp. 133-152). Berlin:

Bildungswerk Berlin. Retrieved from http://www.bildungswerk-

boell.de/sites/default/files/wege zum grundeinkommen.pdf.

Standing, G. (2012b). Cash transfers: A review of the issues in India. UNICEF India: Social Policy Working Paper Series. Retrieved from http://www.guystanding. com/

les/documents/Unicef_cash_transfers_India_published.pdf.

Titmuss, R. (2014). Universalism versus selection. In C. Pierson, F. G. Castles, \& I. Naumann (eds.), The welfare state reader ( $3^{\text {rd }}$ ed.) (pp. 38-45). Cambridge: Polity.

Todd, J., Winters, P., \& Hertz, T. (2010). Conditional cash transfers and agricultural production: Lessons from the oportunidades experience in Mexico. Journal of Development Studies, 46, 39-67. http://dx.doi.org/10.1080/00220380903197945

Van Parijs, P. (1992). Competing justifications for unconditional basic income. In P. Van Parijs (ed.), Arguing for basic income: Ethical foundations for a radical reform (pp. 3-29). London/New York: Verso.

Van Parijs, P. (2004). Basic income: A simple and powerful idea for the twenty-first century. Politics and Society, 32, 7-39. https://doi.org/10.1177/0032329203261095

Westover, J. (2008). The record of microfinance: The effectiveness/ineffectiveness of microfinance programs as a means of alleviating poverty. Electronic journal of sociology, 12 (1), 1-8.

https://www.sociology.org/content/2008/ westover finance.pdf

World Bank (2017a). Namibia. (www.worldbank.org/en/country namibia).

This article is protected by copyright. All rights reserved. 
World Bank (2017b) World Bank poverty and equity database. Retrieved 31.3.2016 From http://databank.worldbank.org/data/.

This article is protected by copyright. All rights reserved. 